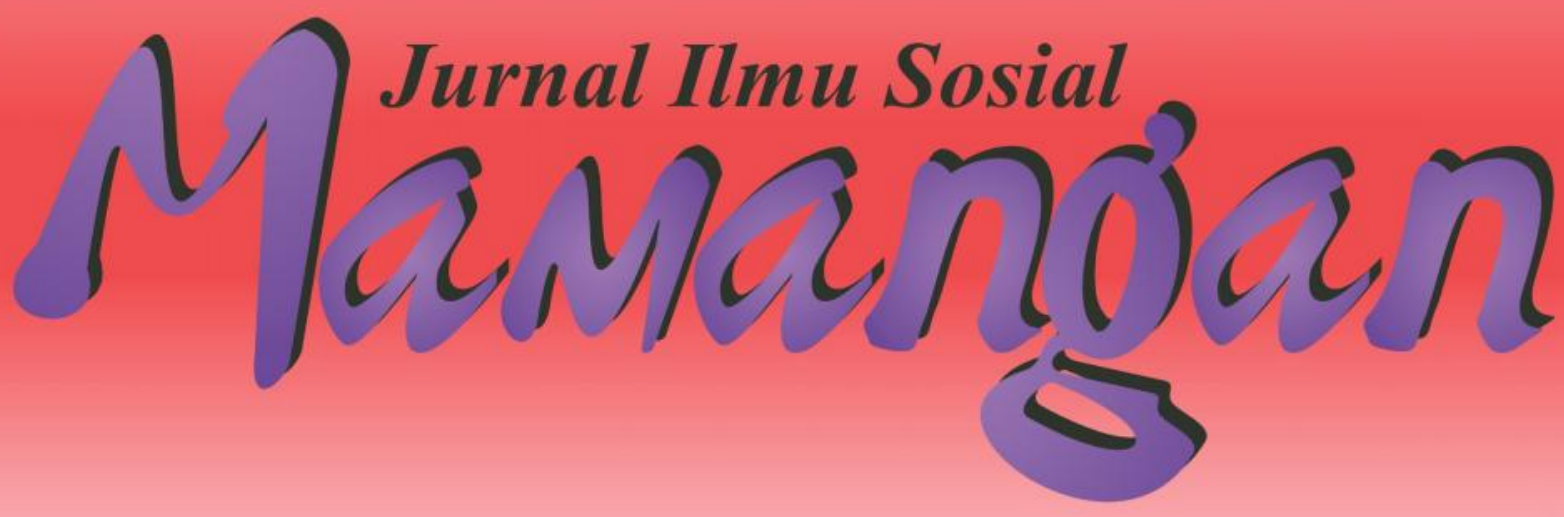

Diamika Perempuan Pedagang Makanan Di Sicincin

Elsa melia Roza, Yulkardi \& Rinel Fitlayeni

Motivasi \& Strategi Keluarga Miskin Nagari Talu, Kab. Pasaman Barat Melanjutkan Pendidikan Anak Ke Perguruan Tinggi

Cici Rahma Sari, Elvawati \& Dian Kurnia Anggreta

Dampak Sosial Ekonomi Objek Wisata The Unique Park Waterboom Di Kota Sawahlunto

Lisa Desatria, Fachrina \& Faishal Yasin

Pandangan Rumah Tangga Sasaran (RTS) Terhadap Pelaksanaan Dana Bergulir PNPM-MP Di Kelurahan Balai Gadang, Kota Padang Elparianti, ArdiAbbas \& Elvawati

Kehidupan Waria Di Jorong Mandiangin, Kecamatan Kinali, Kabupaten Pasaman Barat

Susanki \& Dian Anggraini Oktavia

Fungsi Koperasi Serba Usaha Ekonomi Desa (KSU-ED) Terhadap Masyarakat Nagari Tabek Talang Babungo, Kabupaten Solok Yenti Welia, Witrianto \& Refni Yulia 


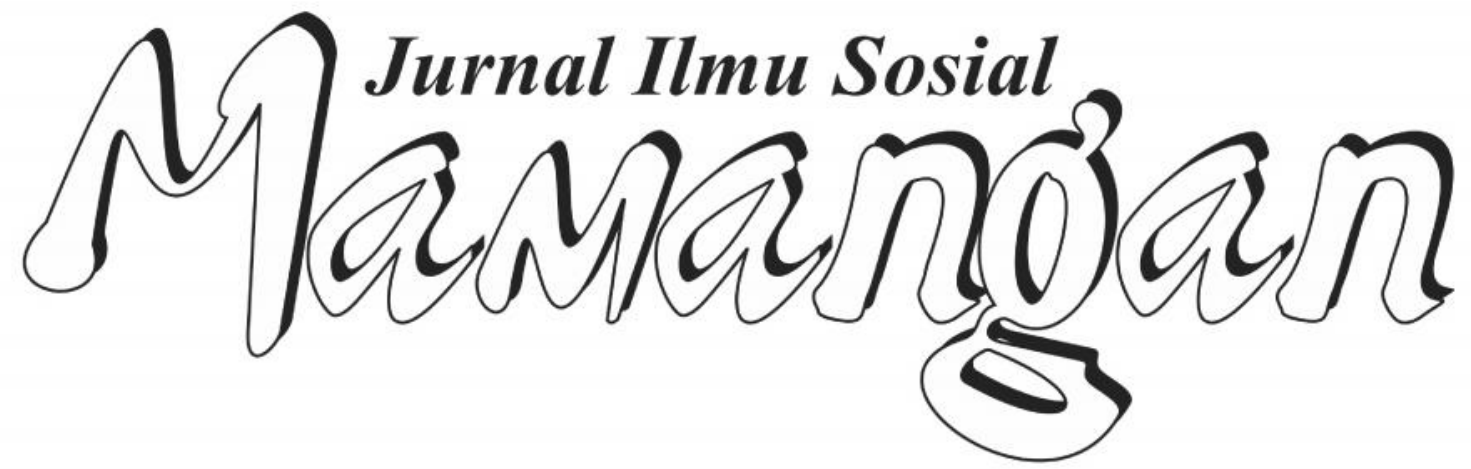




\section{Mitra Bestari}

Prof. Dr. Afrizal, MA. (FISIP, Unand Padang)

Dr. A. Latief Wiyata, M. Si. (Universitas Jember, Jember)

Prof. Dr. Badaruddin, M. Si. (FISIP, USU Medan)

Dr. Fikarwin Zuska, M. Si. (FISIP, USU Medan)

Nurus Shalihin, M. Si., Ph.D. (Fak. Ushuluddin IAIN Imam Bonjol Padang)

Dr. Semiarto A. Purwanto, M. Si. (FISIP, UI Jakarta)

Dr. Wahyu Wibowo, M. Si. (Universitas Nasional, Jakarta)

\section{Dewan Redaksi}

Dr. Zusmelia, M. Si.

Dr. Maihasni, M. Si.

Adiyalmon, S. Ag., M. Pd.

Firdaus, S. Sos., M. Si.

\section{Pemimpin Redaksi}

Firdaus, S. Sos., M. Si.

\section{Anggota Redaksi}

Dian Kurnia Anggreta, S. Sos., M. Si.

Rinel Fitlayeni, S. Sos., MA.

Surya Prahara, SH.

ISSN: 2301-8496

\section{Alamat Redaksi:}

Laboratorium Program Studi Pendidikan Sosiologi, STKIP PGRI Padang

Jl. Gunung Pangilun, Padang

Email: redaksimamangan@yahoo.com

Penerbit :

Program Studi Pendidikan Sosiologi, STKIP PGRI Padang

\section{Contac person :}

Firdaus (Hp. 085263881221/Email : daus gila@yahoo.com) 


\section{DAFTAR ISI}

Diamika Perempuan Pedagang Makanan Di Sicincin

Elsa melia Roza, Yulkardi \& Rinel Fitlayeni.

Motivasi \& Strategi Keluarga Miskin Nagari Talu, Kab. Pasaman Barat Melanjutkan Pendidikan Anak Ke Perguruan Tinggi

Cici Rahma Sari, Elvawati \& Dian Kurnia Anggreta.

Dampak Sosial Ekonomi Objek Wisata The Unique Park Waterboom Di Kota Sawahlunto

Lisa Desatria, Fachrina \& Faishal Yasin

Pandangan Rumah Tangga Sasaran (RTS) Terhadap Pelaksanaan Dana Bergulir PNPM-MP Di Kelurahan Balai Gadang, Kota Padang

Elparianti, Ardi Abbas \& Elvawati

Kehidupan Waria Di Jorong Mandiangin, Kecamatan Kinali, Kabupaten Pasaman Barat

Susanki \& Dian Anggraini Oktavia

Fungsi Koperasi Serba Usaha Ekonomi Desa (KSU-ED) Terhadap Masyarakat Nagari Tabek Talang Babungo, Kabupaten Solok 


\title{
KEHIDUPAN WARIA DI JORONG MANDIANGIN, KECAMATAN KINALI, KABUPATEN PASAMAN BARAT
}

\author{
Susanki \& Dian Anggraini Oktavia \\ Sekolah Tinggi Keguruan dan Ilmu Pendidikan (STKIP) PGRI Sumatera Barat
}

\begin{abstract}
Transgender is social deviation in the community. Deviations made transvestites difficulty in placing itself as part of society in general. Doesn't easy to all people can accept the transvestites are allowed to live and settle in their communities. This article contains the pattern of life of transvestites amongst in the Jorong Mandiangin, to fully accept their existence, and to describe the factors that cause a person to become a transvestite in Jorong Mandiangin District Kinali in West Pasaman. The research approach used a qualitative, descriptive type. Collect data by observation and interviews. The results showed a good relationship between transvestites and society. Although people know that transvestites are an aberration, but the public does not necessarily treat transsexuals with victimization. People are realizing that transvestites are also human beings of divine creation which also has the right to run their lives by working according to his ability. No different to life among fellow transvestites, the visible existence of some form of interaction processes that can unite the transvestites in maintaining the gender status.
\end{abstract}

Keyword: Transsexual, Deviation, Accepted of Society

\begin{abstract}
ABSTRAK
Waria merupakan penyimpangan yang terjadi dalam masyarakat. Penyimpangan yang dilakukan membuat waria kesulitan dalam menempatkan dirinya sebagai bagian dari masyarakat pada umumnya. Tidak semua masyarakat bisa menerima keberadaanya meskipun para waria tersebut dibiarkan hidup dan menetap dalam lingkungan masyarakatnya. Artikel ini memuat pola kehidupan waria ditengah-tengan masyarakat Jorong Mandiangin, yang sepenuhnya menerima keberadaan mereka, serta mendeskripsikan faktor-faktor yang menyebabkan seseorang menjadi waria di Jorong Mandiangin Kecamatan Kinali Kabupaten Pasaman Barat. Pendekatan penelitian yang digunakan dalam kualitatif, tipe deskriptif. Cara mengumpulkan data dilakukan dengan cara observasi dan wawancara. Hasil penelitian menunjukkan terdapat hubungan yang baik antara waria dan masyarakat. Meskipun masyarakat tau bahwa waria adalah suatu penyimpangan, namun masyarakat tidak lantas memperlakukan waria dengan perlakuan tidak baik. Masyarakat menyadari bahwa waria juga manusia ciptaan tuhan yang juga mempunyai hak untuk menjalankan kehidupannya dengan bekerja sesuai dengan kemampuannya. Tidak berbeda dengan kehidupan antar sesama waria, terlihat adanya suatu bentuk proses interaksi yang bisa menyatukan para waria dalam mempertahankan status gendernya.
\end{abstract}

Kata Kunci: Waria, Deviasi, Penerimaan Masyarakat

Jurnal Ilmu Sosial Mamangan, Volume II Nomor 2, juli-Desempber 2013 | 101 


\section{PENDAHULUAN}

Manusia diciptakan sebagai pria dan wanita, dengan melihat fisiknya manusia dapat mengetahui dengan jelas identitas seseorang sebagai pria atau wanita. Keduanya menjalankan peran yang berbedabeda yaitu sesuai dengan jenis kelamin yang telah disandangnya. Anthoni synnot menyatakan bahwa ada pertentangan gender antara wanita dan pria, seperti menggambarkan bahwa pria itu tegas, berjiwa pemimpin, kompetitif, kuat dan agresif. Sebaliknya wanita dianggap lebih lembut, penuh kasih sayang, feminim, halus, emosional dan cenderung menyukai anakanak (Synnot, 2003).

Lingkungan kultural akan selalu terdapat bentuk tingkah laku, perbuatan, cara berfikir, dan gerak-gerak ekspresif yang khusus, khas dilakukan dengan cara-cara feminim dan khusus kelaki-lakian. Hal ini disebabkan karena ada relasi pribadi dan sering sangat intim dengan lingkungan sekitar, yang kemudian diekspresikan keluar dengan cara yang khas kewanitaan ataupun khas kelaki-lakian. Perbedaan ekspresi ini tetap ada, walaupun kaum laki-laki dan para wanita melakukan pekerjaan yang sama. Memang pada hakikatnya wanita mampu bekerja yang sama baiknya dengan kaum laki-laki, namun cara bekerjanya kaum wanita ternyata berbeda dengan cara kerjanya kaum laki-laki, yaitu khas dengan kewanitaanya. Perbedaan-perbedaan itu akan tetap ada, walaupun struktur-struktur sosial didunia dan norma-norma tradisional berubah (Kartono, 1992).

Namun pada kenyataanyan bahwa tidak semua orang bisa menerima dan menjalankan peran serta sifat-sifat yang sesuai dengan status gender yang telah disandang. Mereka mengekspresikan peran dan sifat-sifat yang bertentangan dengan status gender yang sudah ditentukan dalam diri mereka, sehingga mereka harus menyalahi nilai-nilai dan norma yang sudah ditentukan dalam lingkungan masyarakat. Junaidi berpendapat bahwa seseorang bisa saja menyukai aktifitas yang kadang lebih tepat untuk lawan jenisnya ketimbang jenis kelaminnya, mereka menginginkan jenis kelamin yang berlawanan dengan kenyataan fisiknya. Hal itu biasa disebut dengan fenomena transeksual. Transeksual merupakan masalah identitas gender yaitu kesadaran mental yang dimiliki seseorang tentang jenis kelaminnya, tentang apakah dirinya pria atau wanita, mereka merasa terpenjara di dalam tubuh jenis kelamin yang sebenarnya. Transeksual juga merupakan perkembangan fisik yang tidak sesuai dengan keadaan psikisnya. Dari segi genetik dan fisik sebenarnya, para transeksual tidak mengalami masalah, semuanya sesuai dan tidak ada yang salah, hanya kejiwaanya saja yang menolak atau tidak menerima tampilan fisiknya (Junaidi, 2012).

Seorang penderita transeksualisme dengan demikian secara psikis merasa dirinya tidak cocok dengan alat kelamin fisiknya, sehingga mereka seringkali memakai pakaian atau atribut lain dari jenis kelamin yang lain, jika laki-laki ia memakai pakaian perempuan, namun jika perempuan ia memakai pakaian laki-laki. Akan tetapi transeksual sering dialami oleh kaum lakilaki yang biasa disebut waria (Atmojo, 1986). Waria dalam konteks psikologis termasuk sebagai penderita transeksual, yakni seseorang yang secara jasmani jenis kelaminnya jelas dan sempurna. Namun secara psikis cenderung untuk menampilkan diri sebagi lawan jenis. Defenisi waria mengacu pada pengertian bahwa secara fisik mereka adalah laki-laki normal, memiliki kelamin yang normal namun secara psikis merasa dirinya perempuan. Akibatnya perilaku mereka menjadi tampak kaku. Fisik mereka laki-laki, namun cara berjalan, berbicara dan dandan mereka mirip perempuan (Koeswinarno, 2004).

Keberadaan waria ditengah-tengah masyarakat mendapatkan reaksi yang berbeda-beda dari masyarakat itu sendiri. Adanya penolakan-penolakan terhadap waria, menyebabkan waria tidak leluasa dalam menjalani kehidupannya, sehingga mereka relatif sulit untuk memperoleh pekerjaan. Seperti kita lihat kebanyakan waria hanya bekerja ditempat-tempat tertentu, yaitu di salon kecantikan, bahkan ada yang memilih melacur demi memenuhi kebutuhan hidupnya. Seringkali mereka berpindah-pindah tempat tinggal untuk memperluas komunitas dan habitatnya, jadi ruang gerak mereka menjadi lebih luas dan longgar (Kartono, 1992).

Di Jorong Mandiangin para waria tidak dapat sepenuhnya menjalankan nila-nilai 
dan norma yang telah ditentukan, yaitunya mereka tidak mampu menjadi laki-laki. Namun mereka mendapat perlakukan relatif baik. Jika para waria di Kota-kota besar mendapat pelecehan dan berkonflik dengan masyarakat sekitar, tidak demikian halnya di Jorong Mandiangin. Hal ini menjadi menarik untuk dikaji, sehingga tulisan ini mengulas tentang waria dalam masyarakat Jorong Mandiangin Kecamatan Kinali Kabupaten Pasaman Barat, dengan menguraikan pola kehidupan waria, serta faktor penyebab menjadi waria.

\section{TINJAUAN PUSTAKA}

Penelitian tentang waria sebelumnya pernah di rulis oleh Ripo Aprilia dalam skripsi yang berjudul: Potret Kehidupan Waria di Kota Padang. Tulisan tersebut menjelaskan mengenai keberadaan waria yang tidak lagi sembunyi-sembunyi dalam penampakan identitas diri, bahkan waria telah berani menampakkan diri sebagai wanita didepan umum. Salah satu wujudnya dengan adanya kontes ratu waria pada tahun 1995. Kontes waria dilakukan satu kali dalam setahun. Kebanyakan para waria tersebut menjalankan aktifitas mereka sebagai pekerja salon, penjaja seks, serta penyanyi orgen tunggal. Keberadaan waria hanya diterima sebatas bidang-bidang tertentu dan belum sepenuhnya diterima oleh masyarakat (Ripo, 2002).

Penelitian seputar waria juga pernah dilakukan oleh Septi Hariani yang berjudul, Sikap masyarakat terhadap waria; studi komparatif masyarakat kelurahan belakang tangsi Kecamatan Padang Barat dengan masyarakat Lubuk Minturun Kecamatan Koto Tangah. Tulisan tersebut mengulas segala aspek yang berkaitan dengan penerimaan dan penolakan masyarakat terhadap waria. Diduga ada hubungan antara umur, jenis kelamin, dan latar belakang pendidikan dengan sikap masyarakat terhadap waria. Dimana semakin tinggi umur seseorang maka semakin bisa mengambil sikap tentang keberadaan waria (Hariani, 2008).

Kemudian juga ada penelitian yang dilakukan oleh Noviandri, dengan judul: Sosialisasi waria dalam pembentukan identitas diri. Penelitian tersebut menjelaskan bahwa penyebab seseorang menjadi waria diantaranya karena pengaruh sosialisasi. Sosialisasi dalam lingkungan keluarga dengan memperlakukan mereka layaknya seorang wanita, sehingga setelah dewasa mereka berperilaku sebagai seorang wanita. Tingkah laku seseorang ditengah masyarakat baik laki-laki maupun wanita dipengaruhi oleh proses sosialisasi bukan oleh faktor biologis (Noviandri, 2002). Penelitian ini tentu berbeda dengan penelitian sebelumnya, meskipun samasama membahas waria, namun fokus tulisan ini pada kehidupan waria dilingkungan masyarakat pedesaan, dimana masyarakat tersebut tidak membedakan perlakukan pada waria.

\section{METODE PENELITIAN}

Tulisan ini menggunakan metode penelitian kualitatif, mengumpulkan data dengan wawancara dan observasi. Wawancara dilakukan untuk mengumpulkan informasi tentang pola kehidupan waria di Jorong Mandiangin. Observasi dilakukan dengan mengamati interaksi waria dengan masyarakat Jorong Mandiangin, dan mengamati aktifitas yang dilaksanakan oleh waria, seperti pekerjaan yang dilakukan waria. Observasi dilakukan pagi sampai malam, sehingga mengetahui sepenuhnya aktifitas waria. Informan penelitian dalam penelitian ini adalah, para waria, keluarga waria, masyarakat yang berinteraksi dengan waria dan mengetahui kehidupan waria.

\section{POLA KEHIDUPAN WARIA DI JORONG MANDIANGIN}

Mandiangin merupakan daerah yang berada pada tepi pantai yang memiliki penduduk berjumlah 2.319 jiwa. Dari banyak jumlah penduduk yang ada, terdapat 13 waria. Tidak seruhnya waria tersebut saat ini berdomisili di Jorong Mandiangin, dari ke 13 waria, hanya lima waria yang menetap di Jorong Mandiangin, dan 8 diantaranya merantau baik di dalam Provinsi Sumatera Barat, maupun luar sumatera Barat. Waria diwilayah ini ada yang menggunakan nama yang berbeda dengan nama asli mereka. Berikut nama-nama waria yang masih berdomisili di Jorong Mandiangin: Kiki (28 tahun), Memey (26 tahun), Angel, ridho (26 tahun), fidal (24 tahun). Di dalam kehidupannya mereka memiliki pola hidup relatif berbeda. Pola kehidupan waria dalam 
tulisan ini adalah proses interaksi sosial waria dalam masyarakat.

Dalam kehidupan sehari-hari waria bekerja memenuhi kebutuhan hidup mereka. Seperti Kiki bekerja sebagai buruh cuci pakaian. Apabila ada masyarakat yang membutuhkan jasanya, masyarakat yang bersangkutan langsung mengantarkan pakaian kotornya ke rumah Kiki. Tanpa memperhitungkan berapa upah yang didapatkanya kiki berusaha bekerja sebaik mungkin. Setelah semua pekerjaannya selesai barulah kiki memanfaatkan waktunya untuk merawat diri, seperti mandi, bersolek. Pekerjaan kiki memang relatif tidak sulit, namun kiki mengharapkan bisa mendapatkan pekerjaan lain yang lebih baik dari bekerja sebagai buruh cuci pakaian.

Berbeda dengan Kiki, Memey dan Fidal tidak memiliki pekerjaan. Pemenuhan kebutuhan Memey dan Fidal diperoleh dari uang saku yang diberikan orang tua. Namun jika ada masyarkat yang memintanya untuk berjualan keliling kampung, Memey juga mau melakukannya. Menurutnya dengan berjualan Memey bisa membantu meringankan beban orang tuanya, dan memenuhi kebutuhan sehari-hari. Sedangkan Ridho kesehariannya bekerja di counter pulsa. Ridho bekerja mulai pukul 08.00 WIB. Kehidupan waria di Jorong Mandiangin melakukan pekerjaan yang relatif mudah dilakukan. Disamping bekerja waria juga bisa menikmati hidup sesuai keinginannya, asal tidak menyalahi aturan yang ada. Sedangkan Angel bekerja di salon miliknya. Aktifitas bekerja di salon dimulai dari pagi hingga malam hari. Agar lebih jelasnya pekerjaan yang dilakukan waria dapat dilihat pada tabel berikut :

Tabel 1

Daftar Pekerjaan Waria di Jorong Mandiangin

\begin{tabular}{|c|l|c|}
\hline No & Nama & Pekerjaan \\
\hline 1 & Kiki & Buruh Cuci Pakaian \\
\hline 2 & Memey & Tidak Bekerja \\
\hline 3 & Fidal & Tidak Bekerja \\
\hline 4 & Ridho & Conter Pulsa \\
\hline 5 & Angel & Salon Kecantikan \\
\hline
\end{tabular}

Dilihat dari jenis pekerjaan yang dilakukan oleh waria, mereka kesulitan mencari pekerjaan lain, pekerjaan saat ini mereka lakukan adalah pekerjaan yang diperoleh sesuai dengan kemampuan yang dimiliki. Saat ditanya tentang keinginan mendapatkan pekerjaan lain, waria menyatakan ingin memiliki pekerjaan lain, namun sulit untuk mendapatkan pekerjaan lain. Setelah selesai bekerja, aktifitas yang dilakukan waria biasanya merawat diri, jalan-jalan dan berkumpul di salon kecantikan milik Angel.

Secara fisik waria ini merupakan seorang laki-laki, idealnya sebagai laki-laki terdapat ibadah yang umumnya dijalankan oleh laki-laki seperti sholat jumat. Berdasarkan pernyataan pawa waria ini, mereka jarang melaksanakan ibadah sholat jumat. Mereka bingung dalam memutuskan melakukan ibadah tersebut atau tidak. Karena memang secara fisik mereka laki-laki, namun mereka meyakini jiwa mereka perempuan. Tidak hanya persoalan sholat jumat saja, jika beribadah di mesjid mereka kerap bingung, apakah harus berdiri di syaf laki-laki atau berdiri di syaf perempuan.

\section{FAKTOR PENYEBAB MENJADI WARIA}

Faktor penyebab menjadi waria di Jorong Mandiangin menjadi waria adalah: Pertama, merasa jiwa mereka perempuan. Berdasarkan wawancara dengan waria, dinyatakan pada dasarnya tidak ada manusia yang menginginkan kehidupan yang tidak normal, begitu juga dengan waria, namun menjadi waria dianggap sebagai pilihan yang relatif berat. Karena secara fisik dilahirkan sebagai laki-laki, namun memiliki jiwa perempuan. Sehingga meskipun memiliki fisik laki-laki, mereka memiliki jiwa perempuan dan berupaya berpenampilan seperti perempuan. Pilihan menjadi waria awalnya mendapat penolakan dari pihak keluarga, namun keluarga masih melakukan pengontrolan terhadap waria. Kedua, pola asuh yang dilakukan orang tua, mempengaruhi kecenderungan perilaku anak. Dari hasil penelitian orang tua cenderung memperlakukan anak dengan perlakuan yang tidak sesuai dengan jenis kelaminnya, sehingga sampai anaknya tumbuh dewasa mereka menjadi terbiasa dan akhirnya melekat pada dirinya dan membentuk perilaku laki-laki menjadi feminim. Seperti yang dituturkan Memey, orang tuanya pernah menuturkan menginginkan anak perempuan sebelum 
kelahiran Memey. Pola asuh orang tua kerap memperlakukannya dengan manja, ditambah dengan membiarkan Memey bermain dengan teman-teman perempuan. Ketiga, pengaruh lingkungan juga menjadi faktor penyebab menyimpangan tersebut. Hal ini dapat dilihat dengan meningkatnya jumlah waria di Jorong Mandiangin, yang diyakini masyarakat terjadi karena pengaruh lingkungan. Berdasarkan hasil penelitian terdapat remaja yang punya potensi menjadi waria karena memiliki sifat feminim dan berinteraksi dengan waria, secara tidak langsung mempengaruhi mereka menjadi waria.

Pada masyarakat Mandiangin belum ada aturan yang menegaskan mengenai larangan bagi para waria untuk berada pada lingkungan masyarakat. Hal ini menyebabkan waria tidak mendapatkan kesulitan dalam memperoleh pekerjaan. Namun pekerjaan yang dilakukan sesuai dengan keahlian yang dimiliki oleh para waria, seperti menjadi buruh cuci, bekerja di counter pulsa. Berbicara tentang perkembangan waria memang tidak disadari oleh masyarakat, namun pada kenyataannya para remaja sudah ada yang ingin mengikuti jejak para waria yang dianggap sudah senior (telah lebih dahulu memilih menjadi waria). Untuk mengidentifikasi jumlah remaja yang berpotensi menjadi waria memang belum dapat dilakukan. Namun yang realitas dalam masyarakat terdapat remaja yang sudah jelas tampak sisi feminim, seperti: kemayu, yang cara berjalan dan cara bicaranya seperti perempuan, hanya pakaiannya saja yang masih menggunakan pakaian laki-laki.

Pengakuan dari waria, mereka pernah mempengaruhi para remaja yang ada di lingkungannya untuk ikut menjadi waria. Namun tetap saja para remaja tersebut masih belum berani berpenampilan seperti perempuan. Disini tidak ada upaya untuk mencegah pengaruh yang diberikan waria terhadap remaja yang memiliki potensi menjadi waria. Hal yang dilakukan hanyalah pengontrolan yang dilakukan oleh keluarga terhadap remaja yang berpotensi tersebut. Hal yang ditemukan dalam penelitian ini, para remaja yang memiliki potensi tersebut, masih berpakaian seperti laki-laki, karena masih dikontrol oleh orang tua, serta kontrol dari sekolah yang masih "mengikat" mereka untuk tetap berpenampilan sebagai laki-laki.
Jika remaja tersebut menyelesaikan pendidikan formal dan interaksi intens dengan waria, maka mereka berpotensi menjadi waria, bahkan tidak sungkan memperlihatkan identitas sebagai waria di tengah-tengah masyarakat.

Sebagai penderita transeksual, seorang waria juga memerlukan seorang laki-laki untuk dijadikan pendamping dan untuk pelengkap hidupnya. Sama halnya dengan waria di mandiangin yang juga memerlukan pendamping hidup pula untuk pemenuhan seksnya. Namun semua itu tidak lantas membuat waria di mandiangin melakukan pelacuran. Hal ini juga dibenarkan oleh masyarakat, bahwa tidak ditemukan waria yang melakukan pelacuran di daerah tersebut. Waria di Jorong Mandiangin juga memiliki ketertarikan terhadap laki-laki. Seperti saat wawancara dengan Angel, ia mengakui tertarik dengan laki-laki dan menginginkan teman spesial laki-laki.

Interaksi antara waria dengan masyarakat relatif baik. Penerimaan dan penolakan keberadaan waria dalam suatu lingkungan masyarakat tergantung dengan bagaimana waria tersebut menjalani proses kehidupannya dalam masyarakat itu sendiri. Seorang waria diterima atau ditolak di dalam masyarakat sangat ditentukan oleh bagaimana ia membangun relasi dan beradaptasi dengan lingkungan sosial yang ia tempati. Sementara itu masyarakat menerima atau menolak kehadiran waria ditentukan oleh kemampuan waria dalam memperlihatkan perilakunya dalam kehidupan sehari-hari.

Waria merupakan bagian dari masyarakat yang juga dituntut untuk menyesuaikan diri dengan simbol penyimpangan yang ada pada diri mereka. Sebagai individu yang menyimpang waria harus bisa berinteraksi dan berprilaku dengan baik agar masyarkat bisa menerima mereka tanpa melihat simbol penyimpangan yang mereka sandang. Dengan perilaku dan tindakan yang tidak menyimpang dari aturan yang telah ditentukan oleh masyarakat, waria menjalankan kehidupannya hingga akhirnya masyarakat bisa menerima keberadaannya. Meskipun tidak semua masyarkat bisa menerima keberadaannya, waria juga tidak diusir diwilayah tersebut. 


\section{TANGGAPAN KELUARGA TERHADAP WARIA}

Keluarga merupakan orang yang lebih mengetahui dan memahami bagaimana kehidupan waria di mandiangin, karena merekalah orang yang dianggap lebih dekat dengan waria tersebut. Pada umumnya semua orang tua pastinya sangat menyayangi anaknya apapun bentuk dan sifatnya. Begitupun orang tua dan keluarga waria, sebesar apapun penyimpangan yang dilakukan anaknya, mereka saat ini bisa memakluminya. Banyak orang tua yang beranggapan bahwa anak adalah anugrah tuhan yang harus disyukuri, terlepas apakah mereka memilih menjadi waria ataupun tidak. Semua itu dianggap tanggung jawab orang tua, dalam menjaga dan mendidik anak-anaknya.

Demikian pula dengan para orang tua yang memiliki anak seorang waria, mereka juga beranggapan bahwa waria tersebut juga pantas untuk dikasih dan dididik layaknya anak-anak yang lain. Namun mengenai penyimpangan yang dilakukan, dianggap sebagai takdir dari para waria itu sendiri. Mulanya memang mereka tidak senang dengan perilaku mereka, namun lamakelamaan orang tua bisa memahami dan menerima mereka, tidakan yang dilakukan oleh anak-anak mereka.

Bagi keluarga waria, mereka tidak pernah merasa aneh dengan penyimpangan yang dilakukan oleh waria tersebut, dengan begitu tidak ada permasalahan yang dialami waria terhadap keluarganya sudah menerima keberadaannya tanpa merasa terganggu dengan keadaannya. Terlihat adanya interaksi yang baik antara waria dengan keluarganya, malahan ada orang tua yang merasa bangga dengan keadaan waria tersebut, yang tetap dapat melaksanakan pekerjaan. Hal ini dituturkan oleh Ibu Ancam, meskipun memiliki anak laki-laki yang berdandan seperti perempuan, beliau tetap menyayangin Ancam. Ditambah lagi, meskipun kondisinya relatif berbeda, namun tetap dapat bekerja untuk pemenuhan kebutuhan hidup, dan tidak bergantung kepada orang tua.

Dalam kesehariannya, para waria jorong Mandiangin memiliki kebiasaan yang tidak jauh berbeda dengan para perempuanperempuan normal lainnya, mereka suka berdandan, ngerumpi, jalan-jalan dan sebagainya. Kebiasaan-kebiasaan awalnya membuat orang tua dan keluarga khawatir, awalnya mendapat penolakan keluarga, namun keluarga tidak memunyai cara untuk mengatasi perbuatan anak-anak mereka, sehingga sekarang dibiarkan oleh keluarga.

\section{KESIMPULAN}

Pola kehidupan waria dan interaksi waria di Jorong Mandiangin dengan masyarakat sekitarnya relatif baik. Waria tidak mendapat perlakukan diskriminatif dan tidak pula mendapat hukuman sosial seperti dikucilkan dalam masyarakat. Dalam kehidupan sehari-hari waria bekerja sebagai pekerja salon, buruh cuci, buku counter, dan berdagang. Semua aktifitas waria dinilai baik oleh masyarakat, sehingga masyarakat tidak mempunyai alasan untuk tidak menerima keberadaan waria di lingkungan mereka. Meskipun sesungguhnya masyarakat tau bahwa waria adalah suatu penyimpangan. Waria mandiangin juga memperlihatkan hubungan yang baik antara sesama waria. Namun meskipun dipermukaan tidak terlihat penolakan dari masyarakat, dalam proses penelitian ditemukan kekhawatiran masyarakat terhadap potensi bertambahnya jumlah waria diwilayah mereka. Masyarakat menuturkan terdapat interaksi antara waria dengan remaja laki-laki yang memiliki sisi feminim dominan dalam diri mereka, jika tidak segera diambil tindakan, remaja tersebut berpeluang besar kelak ikut menjadi waria. Memang masyarakat tidak menentang keberadaan waria, namun didaerah dengan kultur ketimuran, waria dianggap sebuah penyimpangan.

\section{DAFTAR PUSTAKA}

Atmojo. (1986). Kami Bukan Lelaki. Jakarta: Grafitipers.

Hariani, S. (2008). Sikap Masyarakat Terhadap Waria (Studi Komparatif: Masyarakat Kelurahan Belakang Tangsi Kecamatan Padang Barat dengan Masyarakat Lubuk Minturun Kecamatan Koto Tangah). Universitas Andalas.

Junaidi, I. (2012). Anomali Jiwa. Jakarta: Andi Offset.

Kartono, K. (1992). Patologi Sosial, Mengenal Remaja dan Wanita Dewasa (Jilid 1). Jakarta: Rajawali.

Koeswinarno. (2004). Hidup Sebagai Waria. Yogyakarta: LKS Pelangi Aksara. 
Noviandri. (2002). Sosialisasi Waria dalam Pembentukan Identitas Diri. Universitas Andalas.

Ripo, A. (2002). Potret Kehidupan Waria di
Kota Paang. Universitas Andalas. Synnot, A. (2003). Tubuh Sosial, Simbolisme diri dan Masyarakat. Yogyakarta: Jalasutra. 
